Aksoy, P. (2020). Masallarda yer alan çatışmalara ilişkin bir inceleme: Aytül Akal'ın okul öncesi masallar dizisi örneği. Ana Dili Eğitimi Dergisi, 8(3), 657-674.

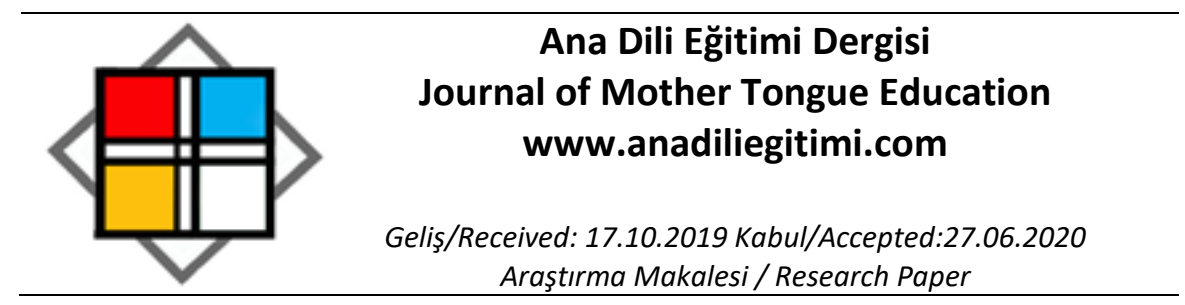

\title{
Masallarda Yer Alan Çatışmalara illişkin Bir İnceleme: Aytül Akal'ın Okul Öncesi Masallar Dizisi Örneği
}

\author{
PInar AKSOY*
}

\begin{abstract}
Öz
Bu çalışmanın amacı, Aytül Akal'ın okul öncesi masallar dizisindeki masallarda öne çıkan çatışmalara ilişkin bir inceleme yapmaktır. Çalışma kümesi, Aytül Akal tarafından yazıımış okul öncesi masallar dizisindeki 20 masal kitabından oluşmaktadır. Çalışma verilerinin toplanmasında doküman inceleme tekniği kullanılmış ve elde edilen çalışma verilerinin analizinde içerik analizinden faydalanıımıştır. Çalışma sonuçları, çalışma kümesindeki masallarda yer alan ana karakterlerin bir kısmının insan, hayvan ve bitki şeklinde canlı varlıklardan oluşurken, bir kısmının da cansız varlıklardan oluştuğunu göstermiştir. Çalışma kümesindeki masallarda öne çıkan çatışmaların yaşanma nedenleri değerlendirildiğinde; masallarda en fazla farklı değer algısı, ardından eğlenme isteği ile güç gereksinimi ve sonrasında özgür olma ve kaynak kısıtılığı nedeniyle çatışmaların yaşandığı ortaya konmuştur. Masallarda öne çıkan çatışmaların çözümlenmesi sürecinde ise davranışın sonucuyla yüzleşme, başka fikirlerle uzlaşma, işbirliği içerisinde olma ve duruma uyum sağlama şeklinde değişen çözüm biçimlerine başvurulduğu saptanmıştır. Çalışmada, Aytül Akal'ın okul öncesi masallar dizisinden incelenmiş olan masalların çatışmaya ilişkin unsurlarının okul öncesi dönem çocuklarına salık verilebilecek bir yapıda olduğu sonucuna ulaşıımıştır.
\end{abstract}

Anahtar Kelimeler: Okul öncesi, masal, karakter, çatışma, çatışma çözümü

\section{An Investigation about the Conflicts in the Fairy Tales: The Sample of Aytül Akal's Preschool Fairy Tales Series}

\begin{abstract}
The purpose of this study is to make an investigation about the conflicts that stand out in the Aytül Akal's preschool fairy tales series. The study set is comprised of 20 fairy tale books in the preschool fairy tales series, written by Aytül Akal. The document analysis technique was used to collect study data and the content analysis was used to analyze the data of the study obtained. The study results showed that some of the main characters in the fairy tales in the study set were composed of living creatures in the form of humans, animals and plants, while some of them were composed of nonliving things. Evaluating the reasons why the conflicts stand out in the fairy tales in the study group occur, it was revealed that the conflicts occur due to different perception of values at the most, then the desire to have fun, and power requirement, followed by being free and limitation of sources. It was found that the conflict resolution manners varying in the form of facing the result of the behavior, agreement with other opinions, being in cooperation, and adaption to the condition were addressed in the process of resolution of the prominent conflicts in the fairy tales. In the study, it was concluded that the factors related to conflicts in the fairy tales among the Aytül Akal's preschool fairy tales series, which were analyzed within the scope of this study, can be recommended to the preschool children.
\end{abstract}

Keywords: Preschool, fairy tale, character, conflict, conflict resolution

\footnotetext{
* Dr. Öğr. Üyesi, Tokat Gaziosmanpaşa Üniversitesi, Eğitim Fakültesi, Temel Eğitim Bölümü, Okul Öncesi Eğitimi Anabilim Dalı, Tokat-TÜRKiYE, aksoypnr@gmail.com, ORCID: 0000-0001-6107-3877.
} 


\section{Giriş}

Sosyal yaşam içerisinde, bireyler birbirleriyle kurdukları iletişim ve etkileşimle bir öğrenme süreci içerisine girmekte ve kişilerarası yaşamın gerektirdiği çeşitli durumlarla karşı karşıya kalmaktadır. Bu süreçte birey kendi yetkinliklerini geliştirmeye yönelik fırsatlar elde ederken, kendisi için zorluk oluşturabilecek veya yaşamında bir engel teşkil edebilecek birtakım durumları da keşfetme gücünü kazanmaktadır. İnsan ilişkilerinde bireylerin birbirlerinin ihtiyaçlarına gerekli olmayan müdahalelerde bulunması veya birbirleriyle değerlerinin uyuşmaması durumunda; zıtlaşma, sürtüşme veya uyuşmazlık yaşanmaktadır. Bu durumlar karşısında ortaya çıkan durum çatışma olarak açıklanmaktadır (Bilgin, 2008). Çatışma sözcüğü, Türk Dil Kurumu'nda [TDK] yapılan bir tanımla, görüş ve kanıların aykırılığından doğan karşıtlık olarak açıklanmaktadır. Başka bir anlatımla, aynı anda ortaya çıkan birbirlerine karşıt ya da eşit derecede çekici dilek ve isteklerin bireyde yarattığı ruhsal durum ile birbirleriyle uyuşmayan dilek, istek veya amaçların yarışmasından ortaya çıkan üzücü bilinç durumu olarak ifade edilmektedir (TDK, 2019). Çatışma, bir eserde yer alan karakterle karşılıkı olarak birbirini geliştiren ve tamamlayan bir unsurdur. Bir eserde karakterin arzusunu gerçekleştirmek üzere harekete geçilmekte ve bu süreçte karşılaşılan zorluklar ile birlikte bir çatışma başlatılmaktadır. Çatışmalar algılar, düşünceler veya değerler ile ilgili durumların bir sonucu olarak da sergilenebilmektedir. Kişilerarası ilişkilerdeki kavga, şiddet, yıkım, uyumsuzluk gibi anlamlara çağrışım yaptığı için genel olarak olumsuz bir durum olarak ele alınmaktadır (Mayer, 2000; Nabokov, 2017; Türnüklü, 2006). İyi yönetilmediği zamanlarda yıkıcı özellikleri olan çatışmaların, olumlu bir süreç olarak ele alınması ve etkili bir şekilde yönetilmesi durumunda, bireysel yaşama ve toplumsal gelişime katkı sağlaması olasıdır (Ozan Demir, 2009). Çatışmaların insan ilişkilerinin ileriye taşınması noktasında önemli bir araç görevi gördüğünün kabul edilmesi sayesinde, çatışmaya yönelik algıların değişmesi mümkündür.

Bireylerin çatışma çözme anlayışına sahip olmaları durumunda yaşadıkları çatışmaları yapıcı bir şekilde çözmeleri ve dolayısıyla çatışma sürecini daha sağlıklı ve verimli yönetmeleri söz konusu olacaktır (Schrumpf, Crawford \& Bodine, 1997). Bireyin/ bireylerin tedirginlik/ rahatsızlık yaşaması, bir durumun yanlış anlaşılması, bireyler arasında gerilimin olması, olumsuz duyguların veya saldırgan davranışların sergilenmesi, içerisinde bulunulan ortamda çatışmanın var olduğunun ipuçları olarak gösterilebilir (Cornelius \& Faire, 1994). Çatışmaların çözüme ulaştırılması noktasında doğasının anlaşıımasına intiyaç duyulmaktadır. Çatışmaların bilişsel, duyuşsal ve davranışsal boyutunun olması da çatışmaların varlığının kestirilmesinde farklı durumların önem arz ettiğini ortaya koymaktadır. Buna göre; çatışmalara ilişkin nesnel ve öznel algılar çatışmaların bilişsel boyutunu, bu süreçteki etkileşim sırasında ortaya çıkan duygular da çatışmaların duyuşsal boyutunu ortaya koyarken, çatışmaların duygulara ve algılara ilişkin durumları ise davranışsal boyutunu ifade etmektedir (Mayer, 2000). Yaşanan çatışmaların iyi yönetilmesiyle birlikte, bireyin kavram, beceri ve davranış edinim süreçleri de desteklenebilmektedir. Bu doğrultuda gözlemle tanık olunan çatışmalardan okuyarak duyumsanan çatışmalara kadar yaşam sürecinde içerisinde bulunulan her bir çatışma durumu, olumlu veya olumsuz yönde bir işleve sahiptir. Bu doğrultuda, sosyal yaşamda gözlenen bir çatışma, televizyonda izlenen bir çatışma, kitapta okunan/dinlenen bir çatışma veya bireyin kendi iç dünyasında yarattığı bir çatışma çocuğun olay ve durumlar karşısında benimseyeceği tutum, davranışlar ve beraberinde öğrenme örüntüleri üzerinde belirleyici konumundadır.

Çocuğun çatışmanın yer aldığı olay kurgusuna tanık olduğu ve ilerideki yaşamına ilişkin tavır ve davranışları öğrenme olanağı bulduğu bir kaynak olan çocuk edebiyatı eserlerinin bu noktadaki payı da oldukça büyüktür. Çocuklara seslenen edebiyat yapıtlarında yazarlar, konuyu oluşturabilmek için yaratıcı güçlerini kullanarak bir olay kurgulamakta iken; kurgulanan her olayda bir çatışmanın yaşanması da kaçınılmaz olmaktadır. Çocuk edebiyatı eserlerinde çatışmaların ele alınış biçimleri, eserlerin yaşamsal durumlar üzerindeki rolü açısından önem taşımaktadır. Bu noktada, çocukları eğitmeye çalışmaktan öteye geçen ve özgürleştirerek bilgilendiren çatışma biçimlerine sahip eserlere intiyaç duyulmaktadır (Sartre, 1988). Lukens (2007) çocuk edebiyatı eserlerinde yer alan karakterlerin davranış ve eylemlerle, konuşma yoluyla, fiziksel özelliklerle, diğer karakterlerin yorumuyla ve anlatıcının yorumuyla geliştirilebildiğini ortaya koymuştur. Çocukların bir edebiyat eserinde yer alan metnin çekim alanına girmesinde, kurgulanan olayda yer alan çatışmaların niteliği belirleyici bir etken konumundadır. Çocukların bir edebiyat eserini okuma eyleminden zevk alabilmesi için, çatışmayı 
yaşayan kahramanla özdeşim kurması ve öykülenen olaydaki gerilimi duyumsaması gereklidir (Sever, 2006). Eserin içerisindeki senaryoda dengesi iyi kurulmuş bir çatışmanın yer almasıyla birlikte, dinleyicinin/okuyucunun eserin sonuna kadar ilgisinin canlı tutulması sağlanabilmektedir (Nabokov, 2017). Bu kapsamda, metnin içerisine giren çocuğun metinle iletişiminin sağlıklı bir biçimde yürümesi ve anlamasına engel bir durumun oluşmaması da eserde yer alan somut göstergelerden kendince soyut anlamlar üretmeye başlamasını ve sezgisel olarak metine yönelttiği sorulara yanıt alarak kendi iletişim ortamını yaratma fırsatı bulmasını sağlamaktadır (Dilidüzgün, 2005). Bu nedenle, çocuk okura seslenen eserlerin olay dizisi boyunca bir gerilim oluşturarak merak duygusunu canlı tutacak biçimde çatışmalar içermesi yanında, çatışma biçimlerinde yer alan iletilerin seslenilen yaş düzeyine uygun öğeleri taşıması gerekir.

Okul öncesi dönem çocuğunun gelişim özelikleri ve doğası gereği, gereksinimleri göz önünde bulundurulduğunda; çocuğun gülmece dünyasına seslenen, dil ve anlatım özellikleriyle çocuğun düş kurmasını sağlayan masalların bu süreçteki yeri önemlidir. Masallar, geçmişte bir zamanda yaşayan insanların genellikle gerçeküstü güçlerle donanmış özellikteki olağan veya olağanüstü varlık ve olaylarla mücadelesinin anlatıldığı ve gerçekle gerçeküstünün harmanlandığı eserler olarak açıklanmaktadır (Güzel \& Torun, 2010). Diğer bir ifadeyle, masallar genellikle olağanüstü kişilere, olaylara yer verilen, anlattıklarına inandırmak için iddiası olmayan, ağızdan ağıza, kuşaktan kuşağa anlatılarak veya yazar tarafından sanat yapmak amacıyla zengin hayal ürünleriyle süslenmiş yazı türleridir (Oğuzkan, 1997). Yaşayan gerçekliği bilmece gibi sunan masallar, çocuğun ruhunu besleyen ve zenginleştiren, çocuğu geleceğe hazırlayan ve gerçeği dolaylı olarak anlatan kaynaklardır (Güneş, 2006). Masallar daha çok olayların geçtiği yer ve zamanı belirli olmayan ve karakterleri genellikle hayvan ve olağanüstü varlıklardan oluşan eserler olarak bilinmektedir. Tür \& Turla'ya (1999) göre, masallarda yer ve zamanlar için; "uzak ülkelerin birinde, yıllar öncesinde ve kaf dağının ötesinde" gibi betimlemelerin kullanıldığı görülmektedir. Bu bakımdan, masalların olayın geçtiği yer ve zamanı belli olmayan ve gerçek olayların veya olağanüstü olayların hayal ürünleriyle süslenmiş bir şekilde ortaya konduğu eserler olması da masalları diğer yazı türlerinden ayıran belirgin özelliklerdir. Masalların dünya folklar tarihindeki yerinden (Abalı, 2013), çocukların becerileri üzerindeki rolüne (llıcak \& Bal, 2019) kadar birçok noktada büyük önem taşıdığı belirtilmektedir. Masallara yedirilmiş önermeler içerisinde bulunulan döneme özgü özelliklerin ve toplumsal cinsiyete yönelik bakışın görülmesi de mümkündür (Sezer, 2004). Masallar kuşaktan kuşağa değerlerin aktarımında önemli rol oynayan eserler olmanın yanı sıra, barındırdıkları çatışmalar yoluyla da yaşamda sorun olabilecek durumların görülmesine, olay ve durumlar karşısında farklı bakış açılarından değerlendirilmesine ve istendik bir şekilde sorun çözme becerilerinin desteklenmesine katkı sağlayacak türden eserler olmaktadır.

İyi ile kötü arasında çatışmaların yer aldığı masalların sonucunda; iyilerin galip gelmesiyle birlikte çocukların belleklerinde iyiliğin ve haklılı̆ın her daim üstün geleceği düşüncesi yer bulmaya başlarken, iyi ve doğru kavramlarını öğrenmeleri de desteklenmektedir. Masal karakterlerinin doğru ve haklı olduğu takdirde zafere ve başarıya ulaşması, iyilik ettiğinde iyilik bulması ve sabrettiğinde mutlaka mutluluğa ulaşması, çocukların bu durumları öğrenmesinde ve bu çerçevedeki toplumsal değerlerin çocuklara aktarılmasında önemli olmaktadır (Karatay, 2007). Bu durumun aksine, henüz nesnel düşünemeyen ve düşle gerçeği ayıramayan okulöncesi dönem çocuğu üzerinde dil ve anlatımı uygun olmayan ve çocuk gerçekliğinden uzak olan masalların olumsuz bir etki yaratması olasıdır. Örneğin; Grimm masallarında olumlanan ceza ve şiddet öğelerinin çocukların olumsuz davranışları üzerinde rolünün olduğu ortaya konmuştur (Güneş, 2006). Ulusal düzeyde yürütülen birkaç çalışmada, okul öncesi dönem çocuklarına yönelik hazırlanan hikâye/masal kitaplarının bir kısmında emir verme/küçümseme, alay etme, ad takma, eleştirme/suçlama ve tehdit etme/gözdağı verme şeklinde iletişim engellerinin yer aldığı ortaya konurken, bahsi geçen iletişim engellerinin çocukta korku, aktif direnç, suçluluk ve bağımlılık gibi durumlara neden olduğu ve çocuğun kendini yetersiz hissetmesine ve benlik saygısının zedelenmesine yol açtığı belirlenmiştir (Kıran, 2008; Tanju Aslışen, 2017). Bu kapsamda çatışmalar kadar bu çatışmaların çözüm biçimleri de önemli olmaktadır. Johnson \& Reed (1996) tarafından çocuk edebiyatı eserleri kullanılarak çocukların çatışma çözme becerilerinin geliştirilmesine yönelik yürütülen sürecin sonunda, çocukların bir çatışmanın ortaya çıkma durumunu net bir şekilde açıklayabildiği ve çatışma çözme biçimlerini tartışabildiği saptanmıştır. Bu durumlar 
masal gibi edebi eserlerin içerisinde yer alan öğelerin okul öncesi dönem çocuğunun nasıl bir yetişkin olacağı noktasında yönlendirmelere sahip olması itibariyle önemli olduğunu ortaya koymaktadır. Bu kapsamdaki alanyazın çalışmalarında, okul öncesi dönem çocuklarına yönelik hikâye/masal kitaplarında yer alan toplumsal cinsiyet olgusunun (Köseler, 2009) veya toplumsal cinsiyet rollerinin (Kaynak \& Aktaş, 2017), söz varlığının (Örge Onuk, 2012), değerlerin (Cengiz \& Duran, 2017; Senek, 2018), iletişim engellerinin (Kıran, 2008) ve çocuk haklarına ilişkin görünümün (Turan, 2011) incelendiği görülmüştür. Alanyazın çalışmaları arasında daha çok öykülere odaklanılmış olmakla birlikte, çocuklara yönelik öykülere ilişkin tercihlerin (Kuzu Sarar, 2002; Yükselen, Yumus \& Işık, 2016) veya çocuk kitaplarına yönelik görüşlerin (Tuğrul, 2002) değerlendirildiği de belirlenmiştir. Okul öncesi döneme seslenen masallarda yer alan kişilerarası çatışmaları inceleyen sadece bir çalışmaya (Ozan Demir, 2009) rastlanmıştır. Dökmen (2010) kişilerarası iletişim çatışmalarının çözümlenmesinde reddedici, yargılayıcı veya önyargılı süreçlerden daha ziyade, empatik bir anlayışın içerisinde olunması gerektiği üzerinde durmaktadır. Masallardaki karakterlerin özdeşim öğesi olarak çocuğun yaşamında önemli olduğu gerçeğinden hareketle, masalda kurgulanmış olan olayların etrafında döndüğü ve çocuğun masal içerisinde konuşması, davranışı veya görünüşü ile tanış olduğu kişi olarak ana karakterlerin bu noktadaki payı büyüktür. Masallarda ele alınan konuların karakterler aracılığıyla çocuğa aktarılması ve olay kurgusu içerisinde bir gerekçeye/nedene dayalı olarak çatışmaların gün yüzüne çıkarılması söz konusu iken, masalların sona ermesiyle birlikte yaşanan çatışmalara ilişkin bir çözüm biçiminin ortaya konması da kaçınılmaz bir durumdur. Buna koşut olarak, masallarda öne çıkan çatışmaların ana karakterlerinin, yaşanma nedenlerinin ve çözüm biçimlerinin birlikte ele alınmasının gerek masallarda benimsenen yapıların görülmesi gerekse de çocuklar üzerindeki olası etkilerinin tespit edilmesi noktasında önemli görülmektedir. Bu noktalar ışığında, Aytül Akal tarafından kaleme alınmış olan okul öncesi dönem çocuklarına yönelik masallardaki çatışmalara ilişkin durumların ayrıntılı bir şekilde incelenmesinin gerekli olduğuna ilişkin bir görüşten hareketle bu çalışma yürütülmüştür. Bu kapsamda elde edilecek bulguların okul öncesi dönemden başlayarak çocuk edebiyatı alanında verilen hizmetlerin niteliğinin artırılması noktasında katkı sağlayıcı olacağı öngörülmektedir.

\section{Çalışma Amacı}

Bu çalışmanın genel amacı, Aytül Akal'ın okul öncesi masallar dizisindeki masallarda öne çıkan çatışmalara iliş̧in bir inceleme yapmaktır. Bu genel amaç doğrultusunda aşağıdaki sorulara yanıt aranmıştır.

1. Aytül Akal'ın okul öncesi masallar dizisindeki masallarda öne çıkan çatışmaların ana karakterleri nelerdir/kimlerdir?

2. Aytül Akal'ın okul öncesi masallar dizisindeki masallarda öne çıkan çatışmaların yaşanma nedenleri nelerdir?

3. Aytül Akal’ın okul öncesi masallar dizisindeki masallarda öne çıkan çatışmaların çözüm biçimleri nelerdir?

\section{Çalışma Modeli}

Yöntem

Aytül Akal'ın okul öncesi masallar dizisindeki masallarda öne çıkan çatışmaların incelenmesini amaçlayan bu çalışma nitel bir çalışmadır. Çalışmada nitel araştırma yöntemlerinden biri olan temel nitel araştırma deseni kullanılmıştır. Aytül Akal'ın okul öncesi masallar dizisindeki masallarda yer alan çatışmaların belirlenmesi amacıyla kullanılan temel nitel araştırma desenindeki bu çalışmada, çatışmaların ana karakterleri, nedenleri ve çözüm biçimleri ile ilgili olarak ne tür durumlar/anlamlar ortaya koydukları üzerinde durulmuştur. Bu doğrultuda çalışmanın veri kaynaklarını, Aytül Akal'ın okul öncesi masallar dizisindeki masallar oluşturmaktadır. Bu kapsamda, çalışma kümesindeki masallarda yer alan çatışmaların ayrıntılı bir şekilde ortaya konması söz konusudur. 


\section{Çalışma Kümesi}

Çalışma kümesini, Uçanbalık Yayınları tarafından yayımlanan ve Aytül Akal tarafından yazılan okul öncesi kategorisi altındaki kitaplardan masallar dizisinde yer alan 52 masal kitabından araştırmacı tarafından amaçlı örnekleme yöntemlerinden kolay ulaşılabilir durum örneklemesiyle temin edilen 20 masal kitabı oluşturmaktadır. Kolay ulaşılabilir durum örneklemesi araştırmacının yakın çevresinde yer alan ve erişilmesi mümkün olan bir durumu/kaynağı seçmesi ile yürütülen, araştırmacıya hız ve pratiklik kazandıran bir örnekleme yöntemidir (Patton, 1987). Bu doğrultuda, Aytül Akal'ın okul öncesi masallar dizisindeki kitaplarda yer alan çalışmaları inceleyen başka bir çalışmaya rastlanmamış olması sebebiyle, çalışma kümesindeki masalların çalışmada incelenmesi amaçlanmıştır. Çalışma kapsamında incelenen masallar; (1)Bu Dünya Kimin?, (2)Ben Büyüküm, (3)Buruşuk Kâğıt Parçası, (4)Bütün Oyuncaklar Benim, (5)Büyük Yatakta Kim Yatacak?, (6)Cadı Burunlu Fabrika, (7)Canı Sıkılan Aydede, (8)Çikolata Çocuk, (9)Denizin Altını Merak Eden Vapur, (10)Dünyanın En Güzel Ağacı, (11)Gezmeyi Seven Ağaç, (12)lşıkları Dolaşan Çocuk, (13)Işığını Yitiren Yıldız, (14)iki Kavgacı Ağaç, (15)Kızamık Olan Fil, (16)Ormanın Renkleri Kimde, (17)Park Yiyen Robot, (18)Rengini Arayan Top, (19)Şımarık Fil ve (20)Yaramaz Trafik Lambası'dır. Bu masal kitaplarında yer alan sayfaların bir kısmı resimden ve bir kısmı yazıdan oluşmakta iken, her bir masal toplamda 16 sayfadan oluşmaktadır.

\section{Verilerin Toplanması}

Nitel araştırma yöntemi doğrultusunda yürütülen bu çalışmanın verilerinin toplanmasında, doküman incelemesi tekniğinden faydalanılmıştır. Doküman incelemesinde, araştırılması hedeflenen bir olgu hakkında bilgi içeren yazılı materyallerin analizi yapılmaktadır. Bu bakımdan dokümanlar, nitel araştırmalarda etkili bir şekilde kullanılması gereken önemli bilgi kaynakları olarak bir görev yapmaktadır. Araştırmacı intiyacı olan veriyi, gözlem veya görüşme yapmaya gerek olmadan, dökümanlar yoluyla elde edebilmektedir (Creswell, 2009; Yıldırım \& Şimşek, 2008). Bu çalışmanın dokümanlarını Aytül Akal tarafından yazıımış olan okul öncesi döneme seslenen masallar dizisinde yer alan 20 masal kitabı oluşturmaktadır. Çalışmanın dokümanlarını oluşturan masallar araştırmacı tarafından birebir gözden geçirilmiş ve her bir masalın içerisinde yer alan çatışma durumları, çalışma amacı doğrultusunda analiz edilmek üzere düzenlenmiştir.

\section{Araştırmacı Rolü}

Bu çalışma, Aytül Akal'ın okul öncesi masallar dizisindeki masallar kapsamındaki metinlerde yer alan çatışma durumlarının tespitine ilişkin adımların eksiksiz bir şekilde takip edilmesi ve önyargıdan uzak bir şekilde değerlendirilmesi üzerine kurgulanmıştır. Bu doğrultuda, çalışma sürecinin başında çalışma kümesinde yer alan masallar, araştırmacı tarafından dikkatli bir şekilde ikişer defa okunmuş ve masallardaki çatışmaların incelenmesi sürecinde her bir alt amaç sorusuna cevap olacak şekilde masallar gözden geçirilmiştir. Bu sayede elde edilen verilerin değerlendirilme sürecinde oluşabilecek herhangi bir veri kaybının önlenmesi hedeflenmiştir. Çalışmanın Aytül Akal'ın masallar dizisinden bir küme masal eşliğinde, eşit sayfa sayısına sahip masallar üzerinde yürütülmesi de masalların seçiminde bir yanlılığın yaşanmaması için bir adımdır.

\section{Verilerin Analizi}

Çalışmada elde edilen verilerin analizinde içerik analizinden faydalanılmıştır. İçerik analizinde, betimsel analizde özetlenen ve yorumlanan verilerin, daha derin bir işleme tabi tutulması ve betimsel bir yaklaşımla fark edilmeyen kavram ve temaların ortaya konması söz konusudur. Buna göre içerik analizinde çalışmada elde edilen verilerin kavramlaştırılması ve ardından ortaya çıkan kavramlara göre mantıklı bir biçimde düzenleme yapılması ve buna dayanarak da veriyi açıklayan temaların ortaya konması izlenen adımlardır. İçerik analizinde verilerin tanımlanması ve verilerin içinde gizli olabilecek gerçeklerin açığa çıkarılması sağlanmaya çalışımaktadır. Bu kapsamda içerik analizi, birbirine benzeyen verilerin belirli kavramlara ve temalara dayanarak bir araya getirilmesi esasına dayanmakta ve bunların okuyucunun anlayabileceği bir biçimde düzenlenerek yorumlanmasını içermektedir (Creswell, 2012; Yıldırım \& Şimşek, 2008). Bu çerçevede çalışma verilerinin içerik analizi ile analiz edilmesi dört aşamada gerçekleştirilmiştir. 
1. Verilerin kodlanması: Bu aşamada araştırmacı çalışma kümesinde yer alan her bir masal için okuma, inceleme ve çalışma soruları ışığında bölümlere ayırma sürecini yürüterek, her masalın kavramsal olarak ifade ettiği anlamları tespit etmeye çalışmıştır. Bu kapsamda masallarda çatışma içerikli tümceler gözden geçirilmiş ve her bir masalda esas olarak öne çıkan çatışma durumları belirlenmiştir. Masallarda yer alan çatışma durumları çalışma amacında yer alan soruların cevaplandırılmasına yönelik olarak ana karakter, yaşanma nedeni ve çözüm biçimi şeklinde isimlendirilmiş ve bunların her biri masallardaki çatışma kodları olarak kaydedilmiştir. Çalışma kümesinde yer alan 20 farklı masalın her biri için bu kapsamda kodlamalar yapılmıştır. Masallarda öne çıkan çatışmalar için ana karakteri, yaşanma nedeni ve çözüm biçimi şeklinde başlıklar altında kodlama yapılarak, farklı masallarda yer alan benzer durumların bir araya getirilmesi sağlanmıştır. Çalışma kapsamında oluşturulan kodlar verilerin değerlendirilmesinde ve düzenlenmesinde anahtar liste olarak kullanılmıştır.

2. Temaların bulunması: Bu aşamada verilerin kodlanması aşamasında belirlenmiş olan kodlardan yola çıkarak, verileri genel düzeyde açıklanabilen ve kodları belirli kategori altında toplayabilen temalar ortaya konmuştur. Masallardaki çatışma durumlarına ilişkin öncesinde belirlenmiş olan kodların bir araya getirilmesinden sonra, çalışma amacında yer alan sorulardan oluşan kodları kapsayacak şekilde temaların oluşturulması sağlanmıştır. Masallarda yer alan tümceler eşliğinde öne çıkan çatışmalar ortaya konurken, bahsi geçen durumu en iyi şekilde temsil eden kavram/sözcük eşliğinde temaların oluşturulmasına özen göstermiştir. Bunu sağlamak üzere alanyazınında çatışma nedeni (Öğülmüş, 2006; Schrumpf, Crawford \& Bodine, 1997; Türnüklü, 2006) ve çatışma çözme biçimi (Ögülmüş, 2006; Johnson \& Johnson, 1991) bağlamında geçen kavramlar/sözcükler gözden geçirilmiş ve tümevarımcı bir yaklaşımla çalışmaya dâhil olan masallarda öne çıktığı saptanan kavramlara göre araştırmacı tarafından tematik bir çerçeve oluşturulmuştur. Bu aşamada çalışma kümesinde yer alan masallar isimlerine göre alfabetik sıraya dizilmiş ve veriler bu sıraya göre işlenmiştir. Verilerin işlenmesine ilişkin örneklere bakıldığında, birinci kodla (ana karakteri) ilgili temalara yönelik olarak Ben Büyüküm adlı masalın küçük olduğunu kabul etmeyen bir çocuk etrafında şekillenmesi ile birlikte, canlı varlık (insan) teması altında ve şımarık Fil masalında kendini çok beğenmiş davranışlar sergileyen bir filin ana rolü üstlenen kişi olması ile canlı varlık (hayvan) teması altında bir değerlendirme yapılmıştır. İkinci kodla (çatılma nedeni) ilgili temalara yönelik olarak Yaramaz Trafik Lambası adlı masalda bir trafik lambasının canının sıkılması ve muziplik yapmak istemesi ile eğlence isteğinden ve Gezmeyi Seven Ağaç masalında bir ağacın yerinde sabit durmaktan yakınarak, hareket etme gereksinimi yola çıkarak çatışma yaratması özgür olma isteğinden kaynaklı çatışma durumu teması altında değerlendirme yapılmıştır. Üçüncü kodla (çözüm biçimi) ilgili temalara yönelik olarak da Kızamık Olan Fil masalında okula gitmek istemeyen filin üzerine uğur böceklerini kondurması ve bunu gören annenin kızamık olduğunu düşünmesi ile filin okula gitmemesi üzerine akşama kadar evde kalarak sıkılması davranışın sonucuyla yüzleşme teması altında ve Rengini Arayan Top masalında renksiz bir topa farklı renklerdeki topların biraz kendi renklerinden vermesi ile topun rengârenk olması işbirliği içerisinde olma teması altında ele alınmıştır. Bu kapsamda, çalışmadan elde edilen bulguları güçlendirmek adına ilgili bölümde sunmak üzere incelenen masallardan doğrudan alıntı tümceleri ve araştırmacı tarafından yapılacak örnek aktarımlar da belirlenmiştir.

3. Verilerin kodlara ve temalara göre düzenlenmesi ve tanımlanması: Bu aşamada masallarda öne çıkan çatışmalara ilişkin olarak verilerin düzenlenmesi yapılırken, elde edilen verilerin açık ve anlaşılır bir şekilde sunulması üzerinde durulmuştur. Çalışma amacı doğrultusunda elde edilen veri seti ilgili tema altındaki kodlara işlenmiş ve bu hali araştırmacı tarafından farklı bir zamanda gözden geçirilmiştir. Bu çerçevede araştırmacı tarafından yapılan analizin sonuçları değerlendirilerek, güvenilir verilere ulaşılması hedeflenmektedir. Bu çerçevede farklı zamanlarda yapılan değerlendirmeler arasında, çatışmanın yaşanma nedeni teması altında yer alan kodun (iki Kavgacı Ağaç ve ışığını Yitiren Yıldız adlı) iki masalda farklılık gösterdiği saptanmıştır. Bu masallara ilişkin yapılan değerlendirmeler araştırmacı tarafından yeniden gözden geçirilmiş ve uygun görülen kodlama altında düzenlenmiştir. Ardından masallarda 
incelenen çatışmalar için güvenilir verileri ortaya koymak üzere okul öncesi eğitimi alanında öğretim üyesi olarak görev yapan ve çocuk edebiyatı üzerine çalışmalar yürüten bir alan uzmanının değerlendirmesine sunulmuştur. Alan uzmanı tarafından çalışma amacına göre her bir masalın çözümlemesi yapılmış ve elde edilen kodların araştırmacı kodlarıyla güvenirliği korelasyon tekniği ile incelenmiştir. Tavşancıl ve Aslan'ın (2001) kodlayıcılar arası güvenirlik= uzlaşma sayısı / uzlaşma + uzlaşmama sayısı şeklindeki formülü kullanılarak; kodlayıcılar arası tutarlılık yapılmıştır. Yapılan hesaplamalar sonucunda, araştırmacılar arasında ana karakter temasında \% 100 (eşit), çatışma yaşanma nedeninde \% 90 (iki masalda farklılaşma) ve çatışma çözme sürecinde \% 85 (üç masalda farklılaşma) oranında bir tutarlılı̆ın olduğu tespit edilmiştir. Tavşancıl ve Aslan'a (2001) göre; güvenilir bir ölçüm için araştırmacılar arası ortalama \% 70'in üzerinde olmalıdır. Çalışmada yer alan temalar altındaki sonuçların bu oranın üzerinde olması ile kodlayıcılar arası tutarlıı̆ın sağlandığı, bir diğer ifadeyle çalışmada güvenilir verilere ulaşıldığı sonucuna ulaşılmıştır.

4. Bulguların yorumlanması: Bu aşamaya kadar ayrıntılı bir biçimde açıklanmış olan bulguların raporlaştırma ilkeleri doğrultusunda ortaya konması ile birlikte, ilgili alanyazın çalışmaları ışığında araştırmacı tarafından yorumlaması yapılmıştır. Bu kapsamda elde edilen çalışma bulgularına neden-sonuç ilişkileri bağlamında açıklık getirilmiştir.

\section{Bulgular}

Çalışma amacı doğrultusunda, okul öncesi dönem çocuklarına yönelik olan masallarda öne çıkan çatışmaların ana karakterlerine, yaşanma nedenlerine ve çözüm biçimlerine ilişkin bulgular bu bölümde yer almaktadır. Bu kapsamda elde edilen bulgular tablolar dâhilinde ortaya konmuştur.

Tablo 1.

Masallarda Öne Çıkan Çatışmaların Ana Karakterleri

\begin{tabular}{lll}
\hline Çatışmaların Ana Karakterleri & Masallar \\
\cline { 2 - 3 } Canlı varlıklar & Insan & $\begin{array}{l}\text { Ben Büyüküm, Bütün Oyuncaklar Benim, Çikolata Çocuk, } \\
\text { Işıları Dolaşan Çocuk, Işı̆ını Yitiren Yıldı. }\end{array}$ \\
\cline { 2 - 3 } & Hayvan & $\begin{array}{l}\text { Büyük Yatakta Kim Yatacak, Kızamık Olan Fil, } \\
\text { Ormanın Renkleri Kimde, Şımarık Fil. }\end{array}$ \\
\cline { 2 - 3 } Cansız varlıklar & $\begin{array}{l}\text { Dünyanın En Güzel Ağacı, Gezmeyi Seven Ağaç, } \\
\text { İki Kavgacı Ağaç. }\end{array}$ \\
\hline Canlı ve cansız varlıklar & $\begin{array}{l}\text { Buruşuk Kâğıt Parçası, Cadı Burunlu Fabrika, } \\
\text { Canı Sıkılan Aydede, Denizin Altını Merak Eden Vapur, } \\
\text { Park Yiyen Robot, Rengini Arayan Top, } \\
\text { Yaramaz Trafik Lambası. }\end{array}$ \\
\hline
\end{tabular}

Tablo 1 incelendiğinde, Aytül Akal’ın çalışma kümesinde yer alan masallarında öne çıkan çatışmaların ana karakterlerinin canlı ve cansız varlıklardan oluştuğu görülmektedir. Bu kapsamda masallardaki ana karakterlerin bir kısmının insan $(f=5)$, hayvan $(f=4)$ ve bitki $(f=3)$ şeklinde canlı varlıklardan ve bir kısmının $(f=7)$ da cansız varlıklardan oluştuğu saptanmıştır. Canlı ve cansız varlıkların bir arada ana karakter olduğu bir masala da rastlanmıştır. Masallarda canlı varlıklardan oluşan ana karakterlere bakıldığında; Ben Büyüküm masalında küçük olmak istemeyen bir çocuk, Bütün Oyuncaklar Benim'de oyuncakları paylaşmayan bir çocuk, Çikolata Çocuk'ta çikolataları çok seven ve perinin dileğini duyması ile her şeyi çikolataya dönüşen bir çocuk, Işıkları Dolaşan Çocuk'ta uyumak istemeyip ışıkları dolaşan bir çocuk ve Işığını Yitiren Yıldız'da sokak lambasını yıldız diye izleyen bir çocuk şeklinde insan kategorisi altındaki ana karakterlerin yer aldığı görülmüştür. Buradaki ana karakterlerinin hepsinin aynı zamanda çocuk olması da dikkat çekici olmuştur. Ayrıca Büyük Yatakta Kim Yatacak?'ta gece olunca kendi yatağında yatmak istemeyip annesiyle babasının yatağında yatan yavru fil, Kızamık Olan Fil'de canı yataktan kalkmak ve okula gitmek istemediği için üzerine 
uğurböceklerini konduran fil, Ormanın Renkleri Kimde'de boş durdukları ve bir işe yaramadıkları için ormandaki hayvanlara kızan ve faydalı işler yapmak için ormandaki bütün çiçekleri toplayıp bir çiçekçi dükkânı açan ayı ve Şımarık Fil'de ormandaki arkadaşlarından çok büyük olduğu için kendini çok beğenmiş davranan bir fil şeklinde hayvan kategorisi altındaki ana karakterlerin yer aldığı saptanmıştır. Dünyanın En Güzel Ağacı'nda bir gün canı çok sıkılan ve saç modelini değiştiren bir ağaç, Gezmeyi Seven Ağaç'ta yemyeşil bir bahçede yaşayan bir ağaç ve İki Kavgacı Ağaç'ta her konuda kavga çıkarıp, huysuzluk eden iki çocuğun diktiği günlerini birbirleriyle çekişip kavga ederek geçiren iki ağaç ise bitki kategorisi altındaki ana karakterler olarak ortaya çıkmıştır.

Masallarda cansız varlıklardan oluşan ana karakterlere bakıldığında ise; Buruşuk Kağıt Parçası'nda yol kenarına bırakılan kâğıt parçası, Cadı Burunlu Fabrika'da fabrikanın peri masallarındaki cadının burnuna benzer koskocaman bir baca, Canı Sıkılan Aydede masalında gökyüzünde canı sıkıldığı için gökyüzünden inip Dünya'da yaşamaya karar veren bir ay, Denizin Altını Merak Eden Vapur'da kıyıdan karşı kıyıya gidenleri taşıyan küçük bir vapur, Park Yiyen Robot'ta çocukların çöpleri karıştırarak yaptıkları ve kendisinin en güzel yerinin çöplük olduğunu sanan bir robot ve Rengini Arayan Top'ta renk seçme gününe geç kalan renksiz bir top ve Yaramaz Trafik Lambası'nda yaptığı işten canı sıkılan biraz da muziplik yapmak isteyen bir trafik lambası şeklinde karakterlerin ana karakter olarak masallarda yer aldığı tespit edilmiştir. Bu Dünya Kimin? adlı masalda da arabalardan başlayarak ağaçlar, yağmur, hava, toprak ve hayvanlar şeklinde canlı ve cansız varlıkların masallara dâhil olduğu görülmüştür.

Tablo 2.

Masallarda Öne Çıkan Çatışmaların Yaşanma Nedenleri

\begin{tabular}{ll}
\hline Çatışmaların Yaşanma Nedenleri & Masallar \\
\hline Güç gereksinimi & $\begin{array}{l}\text { Ben Büyüküm, Bu Dünya Kimin?, İki Kavgacı Ağaç, } \\
\text { Rengini Arayan Top, Şımarık Fil. }\end{array}$ \\
\hline Eğlenme isteği & $\begin{array}{l}\text { Canı Sıkılan Aydede, Denizin Altını Merak Eden Vapur, } \\
\text { Dünyanın En Güzel Ağacı, Işıkları Dolaşan Çocuk, } \\
\text { Kızamık Olan Fil, Yaramaz Trafik Lambası. }\end{array}$ \\
\hline Özgür olma isteği & Büyük Yatakta Kim Yatacak, Gezmeyi Seven Ağaç. \\
\hline Farklı değer algısı & $\begin{array}{l}\text { Buruşuk Kâğıt Parçası, Bütün Oyuncaklar Benim, } \\
\text { Çikolata Çocuk, Işığını Yitiren Yıldız, } \\
\text { Ormanın Renkleri Kimde, Park Yiyen Robot. }\end{array}$ \\
\hline Kaynak kısıtlılı̆ı & Cadı Burunlu Fabrika.
\end{tabular}

Tablo 2'de çalışma kümesindeki masallarda öne çıkan çatışmaların yaşanma nedenleri görülmektedir. Bu kapsamdaki nedenler değerlendirildiğinde; masallarda en fazla farklı değer algısı $(f=7)$, akabinde eğlenme isteği $(f=5)$ ile güç gereksinimi $(f=5)$ ve sonrasında özgür olma $(f=2)$ ve kaynak kısıtııı̆ı $(f=1)$ nedeniyle çatışmaların yaşandığı ortaya çıkmaktadır. Masallarda yer alan anlatımlara bakıldığında, çatışmaların yaşanma nedenlerinin çeşitli şekillerde dile getirilebildiği görülmektedir. Masallarda öne çıkan çatışmaların farklı değer algısından kaynaklı olarak görüldüğü durumlara ilişkin bir örnek olarak; Buruşuk Kâğıt Parçası masalında yere düşen bir kâğıt parçası için arkadaşının "Haydi kaldırıp çöpe atalım" demesi üzerine, çocuğun "Peki ama neden biz kaldırıyormuşuz ki? Büyüklerin işi değil mi bu?" (s.15) diye karşı çıkması da çocuğun çevreyi temiz tutmaya ilişkin sorumluluklarının yetişkin ile çocuk arasında farklılık olduğunu düşündüğünün, bir diğer ifadeyle farklı değer algısına sahip olduğunun bir göstergesidir. Park Yiyen Robot masalında da Robot'un sokak lambalarının aydınlattığı etrafındaki ağaçların şarkı söylediği parkı ve çiçekleri gördüğünde "Ay ne kötü, ne çirkin bir yer burası!" demesi ve "Kendisi paslı teneke ve plastik çöplerden oluştuğu için en güzel yerin çöplük olduğunu sanıyormuş" (s.9) şeklinde açıklamanın yapılması ile çocuklara yardım etmek için etrafı çöplüğe çevirmeye çalışması robotun insanlardan farklı değerlere sahip olduğunu ortaya koyan durumlardır. Burada robotun çocuklara yardımcı olmak için parklara, çiçeklere, ağaçlara, salıncaklara zarar vererek 
oraları çöplüğe çevirmeye çalışması, ancak çocukların bu durumdan memnun olmaması farklı değer algısından kaynaklı olarak yaşanan çatışmaya ilişkin bir örnektir.

Masallarda güç gereksinimi nedeniyle yaşanan çatışma örneklerine bakıldığında; íki Kavgacı Ağaç masalının içeriğinde önce çocukların "Hayır, sen erik ağacını dik! Kiraz ağacını ben dikeceğim!" (s.5)..., "Benim fidanım daha uzun!, Hayır, benimki daha uzun!" (s.5) ve sonra da ağaçların "Hayır, orası benim yerim! Sen çekil!" (s.9) ..., "En kötü yalancı sensin" (s.9) gibi ifadelerle kavga çıkarıp, huysuzluk etmesi güç gereksiniminin karşılanmasına yönelik yaşanan çatışma durumlarını göstermektedir. Yine Şımarık Fil masalında küçük file ait "Ben herkesten büyüğüm!" diye böbürleniyormuş. Büyük olduğu için de kendisini herkesten güçlü, herkesten akıllı ve üstün görüyormuş. Bir gün, "Kimse benim içtiğim yerden su içemez!" diye bağırmış. "Bu göl benim gölüm! Herkes kendine başka bir göl bulsun!" (s.5) tümceleri güç ihtiyacına ilişkin olarak yaşanan çatışmayı ortaya koymaktadır. Çatışmanın eğlenme ihtiyacı nedeniyle öne çıkarıldığı masallardan biri olarak Canı Sıkılan Aydede masalında "Dünyadaki çocukların ne güzel oyuncakları var. Canları hiç sıkılmaz. Ama benim?... Benim hiçbir şeyim yok! Burada can sıkıntısından patıyorum..." (s.15) gibi ifadelerle gökyüzünde yalnız olduğunu, yapacak bir şey bulamadığını ve arkadaşı olmadığı için canı sıkıldığını dile getiren gökyüzündeki Ay'ın eğlenme ihtiyacını gidermesine ilişkin çabaları anlatılmaktadır. Kızamık Olan Fil masalında okula gitmek istemediği için uğur böceklerini üzerine konduran filin halini gören annesinin kızamık olduğunu düşünerek file okula gidemeyeceğini söylemesi ve akşama kadar evde sıkılarak zaman geçireceğini düşünmeye başlayan filin "Anneciğim, ben aslında kızamık değilim. Hemen okula yetişmeliyim, zaten çok geç kaldım..." (s.15) diyerek ve annesinin yanağına hortumuyla tatı ıir öpücük kondurarak yeni bir durumla karşı karşıya kaldığı görülmüştür. Kalabalık iki caddenin kesiştiği bir dört yol ağzında, taşıtlara ve yayalara yol gösteren bir trafik lambasının yer aldığı Yaramaz Trafik Lambası'nda "Bütün günü böyle geçermiş trafik lambasının. Yeşil yandı GEÇ, kırmızı yandı DUR, sarı yandı HAZIRLAN. Sonunda bu işten canı sıkılmış. Aklına biraz da muziplik yapmak gelmiş. Herkese kırmızı ışı yaksa, ne olurmuş acaba?... Belki can sıkıntısı da geçermiş o zaman" (s.5) gibi tümcelerle can sıkıntısını gidermek üzere merak ettiği şeyi deneme ve eğlenme isteği ile bir serüven başlatılmıştır. Özgür olma isteğinden yola çıkarak yaşanan bir çatışmanın yer aldığı masal için de Gezmeyi Seven Ağaç masalı bir örnektir. Burada yemyeşil bahçede yaşayan ağacın bütün diğer ağaçlar gibi, toprağa bağlı, yerinden hiç kıpırdamadan büyümek zorunda olduğunun ve bunun aksine ağacın da çocuklar gibi koşup oynamak, dağlara tırmanmak, denizde yüzmek istediğinin ve çevresindeki evlerin içini merak ettiğinin anlatıldığı görülmüştür. Yine masalın içerisinde rüzgarın bu ağaca neden üzgün olduğu sorulduğunda "Nasıl üzgün olmayayım ki?, Dünyadaki bütün canlılar yüzüyor ya da uçuyor. Ya ben?... Ben burada toprağa çakılıp kalmışım. Oysa dünyayı gezip dolaşmak, yeni yerler görmek isterdim" (s.7) şeklindeki tümcelerle verilen yanıt, ağacın özgür olma isteğinden hareketle yaşadığı duyguyu ortaya koymaktadır.

Çalışma kümesindeki masallar arasında düşük bir oranla yaşanan çatışma durumuna ilişkin bir örnek olarak, Cadı Burunlu Fabrika masalı dikkat çekicidir. Burada dere kenarındaki evlerde oturan ve birlikte oyun oynayan çocukların olduğu ülkede fabrikalardan çıkan zehirli atıkları temizleyen makinelerin olmamasından kaynaklı olarak derenin ve havanın kirlendiği; çiçeklerin, ağaçların, çocukların ve diğer insanların da pis havayı soluduğu, buna karşın uzaylı çocuğun olduğu ülkede fabrika kurulmadan önce, ilk iş olarak temizleme makinalarının yapıldığı anlatılmaktadır. Uzaylı ile Dünya'ı çocuğun ülke kaynaklarında farklılık olduğu iletisi uzaylı çocuğun dere buharı ile kara dumana "Sizin burada işiniz ne?, Bulutlar hiç bu kadar yükseğe çıkmazlardı! şimdiye kadar çoktan yağmur olup dünyaya dönmüş olmanız gerekirdi" (s.9) şeklinde kurduğu tümce ile de pekişmektedir. Buna göre; bir ülkenin kaynaklarında sınırlııkların olmasının bir çatışma yaşanmasının nedeni olduğu, başka bir deyişle kısıtlı kaynakların bir çatışma durumunu ortaya çıkardığı yönünde bir ileti sunulmuştur. 
Tablo 3.

Masallarda Öne Çıkan Çatışmaların Çözüm Biçimleri

\begin{tabular}{ll}
\hline Çatışmaların Çözüm Biçimleri & Masallar \\
\hline Davranışın sonucuyla yüzleşme & $\begin{array}{l}\text { Ben Büyüküm, Bütün Oyuncaklar Benim, } \\
\text { Canı Sıılan Aydede, Çikolata Çocuk, } \\
\text { Denizin Altını Merak Eden Vapur, Dünyanın En Güzel Ağacı, } \\
\text { Işıkları Dolaşan Çocuk, Iki Kavgacı Ağaç, Kızamık Olan Fil, } \\
\text { Ormanın Renkleri Kimde, Yaramaz Trafik Lambası. }\end{array}$ \\
\hline Başka fikirlerle uzlaşma & $\begin{array}{l}\text { Bu Dünya Kimin?, Buruşuk Kâğıt Parçası, } \\
\text { Cadı Burunlu Fabrika, Park Yiyen Robot. }\end{array}$ \\
\hline Işbirliği içerisinde olma & Gezmeyi Seven Ağaç, Rengini Arayan Top, Şımarık Fil. \\
\hline Duruma uyum sağlama & Büyük Yatakta Kim Yatacak, Işığını Yitiren Yıldız. \\
\hline
\end{tabular}

Tablo 3'te masallarda öne çıkan çatışmalar için davranışın sonucuyla yüzleşme ( $f=11)$, başka fikirlerle uzlaşma $(f=4)$, işbirliği içerisinde olma $(f=3)$ ve duruma uyum sağlama $(f=2)$ şeklindeki çatışma çözüm biçimlerine başvurulduğu görülmektedir. Masallardaki çatışmaların çözüm biçimleri arasında en fazla, davranışın sonucuyla yüzleşme yer almıştır. Buna ilişkin örneklere bakıldığında; Ben Büyüküm masalında küçük olmak istemeyen çocuk, cama vuran bir kuşun dileğini yerine getirmesi ile önce abi, sonra da baba olmayı deneyimlemiştir. Abi olduğunda derslerinin çok olduğunu ve baba olduğunda erkenden işe gidip akşam geç saatlerde yorgun eve döndüğünü ve bu deneyimlerinde oyun oynayamadığını görmesinin ardından çocuk olup oyuncaklarıyla oynamanın daha doğru bir seçim olduğuna karar verdiği görülmüştür. Sonuç olarak da çocuğun kendisinin çok istediği bir durumla birebir yüzleşerek içerisinde bulunduğu durumu gönüllü olarak kabul etmesi sağlanmıştır. Bütün Oyuncaklar Benim masalında bütün oyuncakları isteyen çocuğun oyuncaklarını odasında görememesi, oyuncaklarını çok özlemesi ve artık oyun oynayamaması sonucunda "Bir daha kimsenin eşyasını izinsiz almayacağım" (s.15) diye kendi kendine söz vermesi yüzleşme becerisini işleten durumlardır. Canı Sıkılan Aydede masalında gökyüzünden ayrılma isteğinde olan Ay'ın; önce tarladaki ayçiçeği, sonra pastanede ayçöreği olmayı denediği ve ayçiçeği iken toplanıp kamyona doldurulacağını, ayçöreği iken birilerinin onu yiyeceğini gördüğü, akabinde ise kapağında yıldızların olduğu masal kitabını aydınlatan Ay olmayı seçerek hiç sıkılmadığı anlatılmıştır. Dünyanın En Güzel Ağacı masalında; can sıkıntısını geçirmek için saç modelini değiştirmeye karar veren ağaç, saçlarını yana doğru savurmayı, saçlarını dimdik havaya kaldırmayı, saçlarını kendi çevresinde bir kez dolamayı, perçem bırakıp saçlarını gövdesinden aşağıya salmayı denemiş ve nihayetinde yeni yapraklar açarak saçlarını çiçeklerle süsleyerek dünyanın en güzel ağacı olmuştur. Böylelikle ağacın verdiği kararların sonucuyla yüzleşmesiyle, soruna herkesi mutlu eden bir çözüm bulunmuştur. Işıkları Dolaşan Çocuk masalında uyumak istemediği için ışıkları dolaşan çocuk uçağın içine, bir delikanlının kullandığı çok güzel bir arabaya ve kavga eden iki çocuğun olduğu soluk ışıklı eve giderek buradaki durumlarla karşı karşıya kalmıştır. Çocuğun uçakta konuşulan yabancı dili anlamaması, arabayı delikanlının hızlı kullanması ve çocukların birbirlerinin eşyalarına zarar vermesi sonucunda yaşanan durumlardan dersler çıkartarak uyumaya karar vermesi de davranışın sonucuyla yüzleşerek sorunu çözmeye yönelik süreçler olmuştur.

İki Kavgacı Ağaç masalında çocukların itişe kakışa yan yana diktikleri fidanların ağaç olduğunda birbirleriyle çekiş̧ip kavga etmeleri, çiçek açmaması ve meyve vermemesi kavganın ve rekabetin salık verilmeyen bir durum olduğunu ortaya koymaktadır. Ardından, doktorun ağaçlara "Kavgacılığınız yüzünden birbirinizin güneşini engellemiş, köklerinizi aynı yere uzatıp birbirinizin besinini almışsınız. Bu nedenle yardımlaşarak büyüyen diğer ağaçlar gibi gelişememiş, çiçek açamamışsınız?" (s.10) demesinin ardından iki kavgacı ağacın en çok istediklerinin artık çok iyi geçinmek, dost olmak olduğunun belirtilmesi ve artık kavga etmediklerini gören hayvanların onlara yardım etmeye başlaması da davranışın sonucuyla yüzleşmenin etkili bir çözüm yaklaşımı olduğunun göstergesidir.

Çatışma karşısında işbirliği yapmanın önemli olduğu iletisi de masallarda geçen tümcelerle ortaya konmuştur. Örneğin; Gezmeyi Seven Ağaç masalında ağacın koşup oynamak, dağlara 
tırmanmak, denizde yüzmek istemesi ve çevresindeki evleri merak etmesi üzerine rüzgarın "Üzülme, bir çaresini buluruz elbet. Yapraklarından birini bana ver" (s.9) demesi ile kuvvetli esen rüzgârın ardından bir yaprağının evin içine girmesi, bir yaprağın derenin suyuna bırakıldığı, arabanın sileceklerine sıkışan yaprakların çok uzun bir geziye çıktığı ve kamyonun kasasına dolan yaprakların çok uzaklardaki başka ülkelere doğru yola koyulduğu görülmüştür. Rüzgârın ağaç ile yaptığı işbirliği sonucunda ağacın dünyayı gezip dolaşma ve yeni yerler görme isteğinin karşılanmaya çalışıldığı aktarılmıştır. Rengini Arayan Top masalında renklerin seçildiği güne geç kalan bir topa mavi, yeşil, sarı ve kırmızı topların kendi renginden biraz vererek renksiz topu rengârenk boyamaları ve renksiz topun güzel ve canlı olmasını sağlamaları, sorunun çözümü için işbirliği içerisinde olunması gerektiğini örneklendiren bir durumdur. Yine Şımarık Fil masalında filin kendini beğenmiş davranışları karşısında diğer hayvanların çaresiz evlerini toplayıp ormandan ayrıldığının ve kendilerine yeni bir ev bulduğunun, ancak hiçbirinin yeni evinden memnun olmadığının anlatılması kaçınma/çatışma ile sorunun çözümlenemeyeceğini gösteren durumlardır. Sonuçta bir çocuk tarafından onların birlik olmak yerine, kendi çıkarlarına dokunmadığı sürece filin istediği şımarıkığı yapmasına göz yumduklarının ifade edilmesi eşliğinde, bütün hayvanların el ele verip eski ormanlarına doğru yürümeye başlaması ve ardından filin de onları görünce korkup şımarıklıktan vazgeçmesi işbirliğini destekleyen bir durum olmuştur.

Masallarda yer alan çatışmaların bir kısmında ise başkalarının ileri sürdüğü fikirlerle uzlaşma yoluyla sorunların çözümlenebileceği iletisi verilmiştir. Buna ilişkin bir örnek olarak; Bu Dünya Kimin? adlı masala bakıldığında; burada geçen "Söylesene, bu Dünya kimin? Sence hangimizin bu Dünya'da en çok hakkı var?” (s.13) sorusu üzerine çocuğun üzgün üzgün arabalara, ağaçlara, yağmura, havaya, toprağa, hayvanlara bakması ve "Ağabeyimin dediğine göre, Dünya, yalnızca kendini düşünenler yüzünden zaten yaşanmaz hale gelecekmiş,", "Ben öyle bir Dünya'yı ne yapayım? Çok istiyorsanız, alın hepsi sizin olsun!" demesi sonucunda, "Dünya'ya sahip olmak isteyenler şaşkınlıkla birbirlerine bakmışlar. Çocuğun sözlerinden çok utanmışlar. Hepsi sessizce yerlerine dönmüş, Arabalar parkta beklemiş, yapraklar sokaklarda uçuşmuş, yağmur çiselemiş, kuşlar uçmuş..." (s.15) şeklinde ifadeler yer almıştır. Bu durumların akabinde Dünya'nın şimdi çok güzel olduğunun belirtilmesi ile de Dünya'ya sahip olmak isteyenlerin (araba, ağaç, yağmur, hava, toprak ve hayvanlar) çocuğun fikirleri ile uzlaşmaya vardığı sonucuna ulaşılmaktadır.

Çalışma kümesindeki bir masalda ise çatışmaların süreç içerisinde duruma uyum sağlayarak da çözümlenebileceği iletisi verilmiştir. Büyük Yatakta Kim Yatacak masalında kendi yatağında yatmayıp anne ve babasının yanında yatan filin kendi yatağında yatması için anne-babanın çok şişmanlayıp, file yer kalmadığı için onların yatağında uyumaktan vazgeçmesini ve sonrasında bir deri bir kemik kalacak kadar zayıflayarak kemiklerinin küçük file battığı için filin rahat uyuyamayarak yatağına dönmesini denediğinden, filin ise yine anne babasının yatağında uyumaya devam ettiği ve sonrasında her akşam horlayarak küçük fili yataktan kaçırmayı, her akşam yatağında ona masal okumayı ve belki rahat değildir diye yatağını değiştirmeyi denedikleri bahsedilmiştir. Bu durumların hiçbiri çözüm olmazken, bir gece küçük filin artık kendisinin büyüdüğünü düşündüğünde kendi yatağında uyumak istediğini iletmesiyle çatışmanın çözümlendiği görülmüştür. Buna göre; anne-baba filin davranışları karşısında yavru filin geri çekilmesi şeklinde sonuçlanması beklenen çözüm yollarının etkili olmadığına ilişkin iletilerle birlikte süreç içerisinde duruma uyum sağlama stratejisinin işlevselliği öne çıkarılmıştır.

Çalışmadan elde edilen bulgulara göre; masallarda yaşanan çatışmaların çözüm sürecinde yüzleşme, uzlaşma, işbirliği ve uyum gibi yollara başvurulduğunun görülmesi, aynı zamanda güç kullanma, geri çekilme, bedel ödeme, şiddet gösterme gibi olumsuz süreçlere yer verilmediğinin de göstergesi niteliğindedir. Bu durum, çalışma kümesinde yer alan Aytül Akal'ın okul öncesi masallar dizindeki masalların çatışma çözme biçimlerinin tarafların sonuçta mutlu hissetmesini sağlar şekilde ve olumlu yapıdaki çözümler olduğunu göstermektedir. Çatışmaların çözüm biçimlerine bağlı olarak sonuçta tarafların kazanmasının veya kaybetmesinin söz konusu olacağı görüşünden hareketle, çalışma kapsamındaki masalların hepsinin çatışmadaki tarafların çıkarlarını göz önünde bulunduran ve ortak kazanç düzeyini en üst düzeyde tutan kazan-kazan şeklinde bir yaklaşımla sonuçlandırıldığı ortaya çıkmaktadır. Bu çerçevede, Bu Dünya Kimin? masalında "Dünya şimdi çok güzelmiş. Ya çocuk büyüdüğünde?..." (s.16), Buruşuk Kâğıt Parçası'nda "Kâğıdı çöpe atmışlar. Buruşuk kâğıt parçası çok 
mutlu olmuş" (s.16), Dünyanın En Güzel Ağacı'nda "O güzel ilkbahar gününü ve sonraki günleri, mutluluk ve dostluk içinde, neşeyle geçirmişler" (s.16), Işı̆̆ını Yitiren Yıldız'da "Işıklara bakıp gülümsemiş. Bir dilek dilemiş içinden. Onlar da ışıklarını kırpıştırıp çocuğa selam göndermişler" (s.16), Ormanın Renkleri Kimde? masalında "O güzel ve renkli ormanda, tüm hayvanlar, dostluk ve beraberlik içinde mutlu mutlu yaşamışlar" (s.16) ve Park Yiyen Robot'ta "O günden sonra hep o parkta, diğer ağaçlarla birlikte yaşamış. Çöplükleri değil, ağaçları, çiçekleri ve güzel doğayı sevmiş" (s.16) şeklinde tümcelerle masalların sona erdiği görülmüştür. Bu doğrultuda yaşam içerisinde çatışmalarla karşılaşıldığında bir şekilde uygun bir çözüm bulunabileceği ve nihayetinde dostluk, yardımlaşma, işbirliği, barış vb. ile yaşama devam edilebileceği iletisi verilmektedir.

\section{Sonuçlar, Tartışma ve Öneriler}

Çalışma kümesinde yer alan masallardaki çatışmaların farklı farklı ana karakterden yola çıkarak birtakım nedenler eşliğinde başlatıldığı ve çeşitli süreçlerle birlikte çözümlenmeye çalışıldığı belirlenmiştir. Çalışmada incelenen masallarda öne çıkan çatışmaların ana karakterlerinin canlı ve cansız varlıklardan oluştuğu görülürken, insan kategorisini temsilen çocuk ile birlikte bitki ve hayvan kategorisinden karakterlere de yer verildiği tespit edilmiş̧ir. Masallarda kurgulanan çatışmaların içeriğinde ağaç, fil, top, ay, vapur, araba/yağmur/hava/toprak ve trafik lambası gibi ana karakterlerin yer alması, bu karakterlere insana özgü özelliklerin yüklenerek bu karakterlerin kişileştirildiğinin bir göstergesidir. Okul öncesi dönem çocuklarına seslenen kitaplarda yer alan karakterler genellikle fiziksel özellikleriyle (dış görünüşleriyle) ön plana çıkarılmakta, sözleri ve hareketleri ile bir kişilik kazandırılmakta ve resim yoluyla da görselleştirilmektedir. Çocukların yetişkinlerin aksine birçok şeyi ilk kez duyduğunda ve gördüğünde öğrenmeye başlıyor olması nedeniyle, çocukların gördüklerinin ve duyduklarının onların hoşuna gitmesi ve duyu algılarını devindirmesi gerekmektedir (Sever, 2006). Bu kapsamda çocukların hayvan karakterleriyle karşılaşmasının onların dünyasına yeni ve farklı bir duyarılığın kapılarını aralayacağı ve çocuğun süreç içinde bilişsel, duygusal ve eğitimsel yetilerinin gelişiminde etkin bir araç olacağı belirtilmektedir (Uğurlu, 2013). Bu doğrultuda, masallarda geçen çatışmaların ana karakterlerinin çoğunlukla $(\mathrm{f}=15)$ eserin yazarı tarafından yüklenen özelliklere sahip varlıklar (bitki, hayvan veya cansız varlıklar) olduğu ve böylece çocuğu yaratıcı düşünmeye teşvik ederek, çatışmaları etkili bir çözümleme sürecine ulaştırdığı ileri sürülebilir.

Çalışma kapsamına dâhil olan masallardaki çatışmaların kimi zaman çocukların merakını besleyecek kimi zamanda gülme isteklerini yanıtlayacak şekilde yalın bir anlatımla ortaya konduğu ve beraberinde düşünen ve sorgulayan bireylerin yetişmesi noktasında katkı sağlayıcı olabilecekleri sonucuna ulaşılmıştır. Sever'e (2006) göre, okuduğu veya dinlediği karakter ile etkileşim kuran çocuk, kendisi gibi duyan, düşünen ve davranan başka karakterlerin de olabileceğini düşünerek, insan ve toplum yaşamını belirleyen kural ve değerleri tanıma ve anlama bilinci edinmeye başlamaktadır. Yakın bir zamanda Aytül Akal'ın masalları üzerinde yapılan bir çalışmada (Senek, 2018) masallarda adaletli olma, arkadaşık, barış, cesaret, çalışkanlık, dayanışma, doğruluk, duygudaşlık, fedakârlık, kanaatkârık, özgürlük, sabırlı olma, sağlıklı olmaya önem verme, saygı, sevgi, sorumluluk, şükretme, tasarruf etme, temiz olma, yardımlaşma gibi değerlerin yer aldığı saptanmıştır. Bu değerleri duyumsatan/sezdiren masallarla büyüyen çocukların sevginin her kapıyı açabileceğine, iyi ile doğrunun er ya da geç kazanacağına, dünyanın adaletle ve saygıyla daha da yaşanılabilir hale geleceğine yönelik inancının güçleneceği bir gerçektir. Çocuğun kendisinin de toplumun bir bireyi olduğunu sezmesi, topluma karşı bazı sorumluluklarının olduğunun farkına varması ve kendisinin de doğru adımları takip ederek dünya barışına katkı sağlayabileceğini anlaması olası olacaktır. Öte yandan; çalışma kapsamındaki masallarda öne çıkan çatışmaların ana karakterleri arasında padişah, kral, cadı gibi efsunlu varlıkların yer almaması çocuğu eşitlikçi olmayan bir anlayıştan koruyan bir durum olurken, kadına veya erkeğe yüklenen rollerin geleneksel bir bakış açısıyla oluşturulmamış olması da çocuğu kalıpyargısal yaklaşımdan uzak tutan bir durumdur. Masal kitaplarında toplumsal cinsiyet olgusunu inceleyen Köseler'in (2009) çalışmasında, masallarda kız çocukların ev işlerinde ve erkek çocukların alışveriş işinde yardım etmesi şeklinde örneklerin yer aldığı belirlenmiştir. Değişen modern yaşam düzeninde eşitlikçi olmayan yaklaşımların varlığı da özgün düşünme, esnek bir bakış açısına sahip olma ve yansız değerlendirme gibi durumlar üzerinde engelleyici bir etmendir. 
Çalışma kümesindeki masallarda farkıı nedenlerden kaynaklı çatışmaların yaşandığı iletisi verilirken, ortaya konan nedenlerin de çocuğa görelik ilkesine uygun olarak yapılandırıldığı dikkat çekmektedir. Buna göre; incelenen masallar arasında en fazla "farklı değer algısı" nedeniyle (Buruşuk Kâğıt Parçası, Bütün Oyuncaklar Benim, Çikolata Çocuk, Işığını Yitiren Yıldız, Ormanın Renkleri Kimde, Park Yiyen Robot) çatışma yaşandığının görülmesi, çocukluk döneminde farklı hayal gücü ve farklı düşünce yapısının hâkim olduğunun bir ifadesi niteliğindedir. Buna ilişkin örneklerde; (Park Yiyen Robot'ta) dünyanın çöpe dönüştürülmesinin güzel olduğu gibi yanlış bir algının somut bir şekilde ortaya konması veya (Buruşuk Kâğıt Parçası'nda) kâğıt parçasını çöpe atmanın çocuklardan çok yetişkinlerin sorumluluğunda olduğuna ilişkin bir görüşün de mevcut olabileceğinin sezdirilmesi "değer algısındaki farklııkları" açıklayan durumlardır. Çatışmanın yaşanmasına neden olan bu gibi farklı değer algılarının yargılanmadan ortaya konması, çocukların kendilerini ve çevresini sorgulama sürecini de başlatmaktadır. Diğer bir açıdan, bu durumlar çocukların yetişkinden farklı bir bakış açısına sahip ve aynı zamanda öğrenme deneyimleri desteklenmesi gereken kişiler olduğunu göstermektedir. Çalışma kümesinde yer alan kimi masallardaki çatışmaların eğlenme isteğinden kaynaklı olarak (Canı Sıkılan Aydede, Denizin Altııı Merak Eden Vapur, Dünyanın En Güzel Ağacı, Işıkları Dolaşan Çocuk, Kızamık Olan Fil, Yaramaz Trafik Lambası) çıktığııın belirlenmesi ise okul öncesi dönem çocuğunun doğası gereği beklenilen bir durumdur. Örneğin; bir masalda (Canı Sıkılan Aydede) karakterin oyuncaklarının olmadığı ve arkadaş edinemediği, bu nedenlerle canının sıkıldığı vurgulanmıştır. Bir diğer masalda (Işıkları Dolaşan Çocuk) da çocuğun uyumak istemediği ve başka yerlerde olmak istediği, neticede eğlenceli olabileceğini düşündüğü durumları yerine getirmeyi denediği görülmüştür. Bu süreçler, okul öncesi dönem çocuklarının yaşamında sıklıkla karşılan durumların eserin yazarı tarafından duyarlılıkla kaleme alınmış hali olarak değerlendirilebilir.

Güç gereksiniminden dolayı yaşanan çatışmaları öne çıkaran masallarda (Ben Büyüküm, Bu Dünya Kimin?, Iki Kavgacı Ağaç, Rengini Arayan Top, Şımarık Fil) kendisinin küçük olduğunu kabul etmek istememe (Ben Büyüküm), dünyanın sahibi olduğunu düşünme (Bu Dünya Kimin?) ve kendi isteklerini ön planda tutma (iki Kavgacı Ağaç) gibi durumların duyumsatılması okul öncesi dönem çocuğunun olay ve durumlara bakış açısı ile örtüşen durumlardır. Nitekim Freud'un bilişsel gelişim kuramında, okul öncesi dönem çocuğunun egosantrik düşünme ve benmerkezci davranma gibi özelliklerin görüldüğü işlem öncesi dönemde olduğu vurgulanmaktadır. İçerik bakımından sözü edilen bu masallar, çocuk okurun masalın yarattığı sezgisel dünyada kendinden örnekler bulmasını ve masalın içine girmesini sağlayacak masallardır. Özgür olma isteğinden yola çıkarak yaşanan çatışmaları öne çıkaran masallarda (Büyük Yatakta Kim Yatacak ve Gezmeyi Seven Ağaç) da buna koşut durumlara rastlanmaktadır. Örneğin; masalın birinde (Gezmeyi Seven Ağaç) olduğu yerde sabit durmadan başka yerlere gitme ve dünyayı gezip dolaşma isteğinde olduğunu dile getiren ağacın, bu isteğinin yerine getirilememesinden dolayı üzüntü duyması ve aynı şekilde bir başka masalda (Büyük Yatakta Kim Yatacak) yavru filin anne-babasının yatağından onlar istediği zaman değil de kendisi buna hazır olduğunda ayrılarak kendi yatağında uyumaya başlaması özgürlük gereksinimi adına duyarlılık uyandıran durumlardır. Dolayısıyla, sözü edilen masallarda çatışmaların yaşanması büyük oranda temel gereksinimlere (güç, eğlenme ve özgür olma isteği) veya farklı değer algısına dayandırııırken, nadiren de kısıtlı kaynaklar nedeniyle gerçekleştirilmiştir. Bu durum, incelenen masallardaki çatışmaların kin, nefret, öfke, kıskançlık gibi uygun olmayan nedenlere dayandırılmadığının bir ifadesi olarak değerlendirilirken, çocukların sevgi gereksinimlerinin yanıtlanması noktasında da etkili metinler olduklarını göstermektedir. Maslow'un intiyaçlar hiyerarşisine karşılık olarak okul öncesi dönem çocuklarının biyolojik ihtiyaçları ile güvenlik ihtiyacından başlayarak, ait olma, saygınlık, kendini kanıtlama, entellektüel, duygusal ve estetik gereksinimlerine kadar devam eden gereksinimleri bulunmaktadır. Okul öncesi dönem çocuğu için hareket etme, eğleneceği şeylerle meşgul olma ve kendini ifade etme gibi gereksinimlerin olması da doğal bir süreçtir. Bu süreçlerin nitelikli eserler aracılığıyla etkili bir şekilde çocuğa duyumsatılması çocukların eserle duyuşsal açıdan sağlıkı bir etkileşim içerisinde olabilmesi noktasında önemlidir. Çünkü çocuğa haz veren ve doyum sağlayan etkinliklerin çocuk tarafından tekrar edilmesi çok daha olası olacağı için okuma kültürünün edinilmesi noktasında da böylesi eserlere intiyaç duyulmaktadır. 
Çatışmaların çözümlenme biçimi sağ|ıklı bir şekilde çözümlenip çözümlenemediğini ortaya koyarken, çatışma sonucunda tarafların hissettiği duyguyu ve çatışmadan elde edilebilecek iletileri de açığa çıkarmaktadır. Bu nedenle, çalışma kapsamında incelenen masallardaki çatışmaların şiddet gösterme, güç kullanma, geri çekilmesini sağlama gibi yollarla değil, problem durumunu görme-onunla yüzleşme ve sorunu çözmek için uzlaşma-işbirliği yapma şeklindeki yapıcı sorun çözme stratejileri ile çözüme kavuşturulduğu belirlenmiştir. Bu kapsamda çalışmadaki masallarda çatışmaların kazan-kazan şeklinde bir yaklaşımla çözüme kavuşturulmuş olması ve sonuçta tarafların mutluluğa ulaştığının anlatılması çocukların gelişimlerini destekleyebilecek türden masallar olduğunun da bir ifadesidir. Masalların mutlu sonla bitirilmesiyle, çocukların dünyasında olumlu etkilerin yaratılması, zihinlerine adalet ve dürüstlük düşüncesinin yerleştirilmesi ve ahlak gelişimlerinin desteklenmesi mümkün olmaktadır (Yalçın \& Aytaş, 2005). Masallarda yer alan olaylardaki olağanüstü durumlar çocuklar için ilgi çekici bir şekilde sunulurken, onların hayal gücünün ötesinde de kalmamalıdır. Sihir, büyü gibi yollarla değişimin meydana geldiği olaylar yerine, hayal öğeleri ile bezenmiş olaylara yer verilmesi uygundur (Tür \& Turla, 1999). Bu kapsamda incelenen masallarda insan olmayan ana karakterlere çocuğun hayal gücünü destekleyecek şekilde insana özgü özelliklerin yüklenmesi ile düşünme ve konuşma gibi yetilerin kazandırıldığı ve bunun sonucunda ulaşılan bir yargıyla çözüm yoluna karar verilmesinin söz konusu olduğu görülmüştür. Örneğin; kavgacı ağacın meyve vermemesi ve ters çalışan trafik lambasının düzeni bozması sonucunda, efsunlu yollara başvurulmasına gerek olmadan uygun olmayan davranıştan vazgeçilmesinin karakterleri birlik-beraberliğe ve huzura götüren bir yol olduğu ortaya konmuştur. Bir bakıma kişileştirme sanatından faydalanılarak, çocuk okurun yaşanan çatışmanın sonucunu görmesi ve uygun davranışa yönelmesi desteklenmiştir. Bu kapsamda, incelenen masallardaki çatışmaların yaşanma ve çözümlenme sürecinin gerçek yaşamdan kesitler içermesi ile çocuğun yaşam deneyimlerinin geliştirilmesi noktasında katkı sağlayıcı olacağı düşünülmektedir. Masallarda çocukları boş (batıl) inançlara, uyuşukluğa ve kaderciliğe yönelten telkinlerden kaçınılması şarttır. Çocuklara benimsetilmek istenen değerlerin masallarda yer alan iletiler aracılığıyla masalın içerisine serpiştirilmesi gerekmektedir (Oğuzkan, 2000). Yaşam süreci içerisinde bireyin çatışmalar yaşamaması veya sorunla karşılaşmaması neredeyse imkânsızdır. Masallarda çocuklara duyumsatılan çatışmaların korkutucu veya zedeleyici olmaması da çocukların sorunla baş etme yetisine sahip güçlü karakterlerde yetişkinler olmaları noktasında önemli bir adımdır. Ilıcak \& Bal'ın (2019) çalışmasında, masal terapisine katılan okul öncesi dönem çocuklarının sosyal iletişim becerilerinin daha iyi düzeyde olduğu tespit edilmiştir. Bu durumla birlikte, çalışma kapsamında incelenen masalların bu anlamda katkı sağlayıcı bir şekilde kullanımının uygun olabileceği yönünde bir sonuca ulaşılmaktadır.

Masalların çocuğun dünyasında kendine yer bulabilmesi ve çocukta okuma isteği uyandırabilmesi için gerek karakterleri gerekse içeriği bağlamında çocuk için çekici türden çatışmalarla kurgulanmış olması gerekmektedir. Okul öncesi dönem çocuklarına seslenen masallardaki çatışma unsurları çocukların sorunlarını şiddete başvurmadan çözebilen, başkalarının sorunlarına karşı duyarlı davranabilen, başkalarının kendini iyi hissetmesine yardımcı olmaya çalışan ve kendi sorumluluklarının ve sınırlarının bilincinde olan bireyler olarak yetişmesi noktasında büyük önem taşımaktadır. Bu süreçte; okul öncesi öğretmenlerine, ailelere, yayınevlerine, ilgili bakanlıklara (Milli Eğitim Bakanlığı, Kültür ve Turizm Bakanlığı gibi), çocuk edebiyatı yazarlarına ve sivil toplum örgütlerine önemli sorumluluklar düşmektedir.

Çalışma bulgularından hareketle, Aytül Akal'ın masallar dizisi içerisinde incelenmiş olan kitapların çatışmaya ilişkin öğeler bakımından okul öncesi dönem çocuklarına salık verilebilecek bir yapıda olduğu sonucuna ulaşılmıştır. Okul öncesi dönem çocuklarının çalışma kapsamında yer alan Aytül Akal'ın masallar dizisindeki eserler gibi çocuğa görelik ve çocuk gerçekliği ilkesine uygun yapıdaki eserlerle buluşturulması son derece önemlidir. Bu doğrultuda, okul öncesi eğitimin paydaşları arasında yer alan öğretmenlerin ve ebeveynlerin yazılı, sözlü ve görsel iletişim kaynaklarından faydalanılarak, nitelikli çocuk edebiyatı eserleri konusunda yüksek bilinç ve duyarlılık seviyesine ulaştırılması şarttır. Yazarlar tarafından kaleme alınan eserlerde yer alan çatışmaların sahaya sunulmadan önce ilgili birimler tarafından gözden geçirilmesini sağlayan bir denetim mekanizmasının oluşturulmasının yanında, öğretmenlerin ve ebeveynlerin dinleyici veya okuyucu çocuk için yetkince yapılandırılmış yapıtları seçebilme yetkinliğine sahip olması son derece gerekli bir durumdur. Bu durumlar sayesinde 
çocuklarda okuma isteğinin uyandırılması ve akabinde çocukların kendini geliştiren, eğiten ve yenileyen karakter özelliklerine sahip bireyler olarak toplumda var olması noktasında masalların katkı sağlayıcı olması söz konusu olacaktır.

Bu çalışmada okul öncesi dönem çocuklarına seslenen Aytül Akal'ın masallar dizisinde yer alan kitaplarda öne çıkan çatışmaların ana karakterleri, çatışma nedenleri ve çözüm biçimleri odağında bir değerlendirmesi yapılmıştır. Ileride yapılacak çalışmalarda, farklı yayınevleri tarafından yayımlanan masal ve öykü kitaplarında öne çıkan çatışma durumları karşılaştırılabilir ve bu çatışma durumlarının belirlenmesine ilişkin öğretmenlerle odak grup görüşmesi yapılabilir. Masallarda öne çıkan çatışmaların çözüm biçimlerinin çocukların sorun çözme becerileri üzerindeki etkisi, deneysel bir çalışma ile incelenebilir. Masallarda yer alan çatışma durumlarının çocuklar üzerindeki etkisi, çocukların yaptıkları resimler ve ürün dosyaları (portfolyoları) aracılı̆ıyla boylamsal olarak analiz edilebilir.

\section{Kaynaklar}

Abalı, i. (2013). Yapısal folklor kuramı bağlamında bir masal incelemesi örneği. idil, 2(8), 26-40.

Bilgin, A. (2008). Okullarda şiddeti önlemede bir yöntem çatışma çözme. Bursa: Ezgi Kitabevi.

Cengiz, Ş., \& Duran, E. (2017). Analysis of values on preschool period children story and tale books. Education and Science, 42(191), 205-233.

Cornelius, H., \& Faire, S. (1994). Everyone can win. How to resolve conflict. Australia: McPherson's Printing Group.

Creswell, J. W. (2009). Research design: Qualitative, quantitative, and mixed methods approaches (3rd edition). Thousand Oaks, CA: Sage Publications.

Creswell, J. W. (2012). Educational research: Planning, conducting, and evaluating quantitative and qualitative research (4th edition). Upper Saddle River, NJ: Pearson/Merrill Prentice Hall.

Dilidüzgün, S. (2005). Çocuk edebiyatı ve eğitsel özellikleri. M. Sevinç (Yay. Haz.). Erken çocuklukta gelişim ve eğitimde yeni yaklaşımlar-1 içinde (ss.197-203). İstanbul: Morpa Kültür Yayınları.

Dökmen, Ü. (2010). Sanatta ve günlük yaşamda: iletişim çatışmaları ve empati. İstanbul: Remzi Kitabevi.

Güneş, H. (2006). Grimm masallarının çocuklar üzerindeki etkileri. Yayımlanmamış Doktora Tezi, Anadolu Üniversitesi Sosyal Bilimler Enstitüsü, Eskişehir.

Güzel, A., \& Torun, A. (2010). Türk halk edebiyatı el kitabı. Ankara: Akçağ Yayınları.

llıcak, N. G., \& Bal, F. (2019). Masal terapinin anaokulu öğrencilerinin sosyal iletişim becerileri üzerindeki etkisinin incelenmesi. Avrasya Sosyal ve Ekonomi Araştırmaları Dergisi, 6(3), 517533.

Johnson, D. W., \& Johnson, F. P (1991). Joining together. Boston: Allyn and Bacon.

Johnson, J., \& Reed, F. (1996). Improving students ability to resolve conflict. Unpublished Master's Thesis, Saint Xavier University IRI/Skylight Field Based, Chicago.

Karatay, H. (2007). Dil edinimi ve değer öğretimi sürecinde masalın önemi ve işlevi. Türk Eğitim Bilimleri Dergisi, 5(3), 463-475.

Kaynak, D., \& Aktaş, E. (2017). Okul öncesi hikâye ve masal kitaplarında toplumsal cinsiyet rolleri. EKEV Akademi Dergisi, 21(72), 67-85.

Kıran, S. (2008). Okulöncesi dönemi çocuklarına yönelik hazırlanan masal ve öykü kitaplarında geçen iletişim engelleri. Yayımlanmamış Yüksek Lisans Tezi, Adnan Menderes Üniversitesi Sosyal Bilimler Enstitüsü, Aydın.

Köseler, F. (2009). Okul öncesi öykü ve masal kitaplarında toplumsal cinsiyet olgusu. Yayımlanmamı̧ Yüksek Lisans Tezi, Adnan Menderes Üniversitesi Sosyal Bilimler Enstitüsü, Aydın.

Kuzu Sarar, T. (2002). Öykünün çocuğun bilişsel ve duyuşsal gelişimine katkısı bağlamında öykü seçimi. Eğitim Araştırmaları Dergisi, 9(ÖS-III), 95-105.

Lukens, R. J. (2007). A critical handbook of children's literature (6th edition). Boston: Allyn \& Bacon.

Mayer, B. (2000). The dynamics of conflict resolution: A practitioner's guide. San Francisco: Jossey-Bass.

Nabokov, V. (2017). Edebiyat dersleri. A. L. Batur \& F. Özgüven (Çev.), (4. baskı). İstanbul: İletişim Yayınları.

Öğülmüş, S. (2006). Kişilerarası sorun çözme becerileri ve eğitimi. Ankara: Nobel Yayın Dağııım. 
Oğuzkan, A. F. (1997). Yerli ve yabancı yazarlardan örneklerle çocuk edebiyatı (5. baskı). Ankara: Emel Matbaacilı.

Oğuzkan, A. F. (2000). Çocuk edebiyatı. Ankara: Anı Yayıncılık.

Örge Onuk, E. (2012). Adapazarı merkez ölçesindeki okul öncesi kurumlarında okutulan masalların söz varlığının 6 yaş çocukları düzeyine uygunluğu (Sakarya örneği). Yayımlanmamış Yüksek Lisans Tezi, Sakarya Üniversitesi Eğitim Bilimleri Enstitüsü, Sakarya.

Ozan Demir, Y. (2009). Çocuk masallarında kişilerarası çatışma çözme süreci. Yayımlanmamış Yüksek Lisans Tezi, Ankara Üniversitesi Eğitim Bilimleri Enstitüsü, Ankara.

Patton, M. Q. (1987). How to use qualitative methods in evaluation. Newbury Park, CA: Sage Publications.

Sartre, J. P. (1988). "What is literature?" and other essays. Cambridge, MA: Harvard University Press.

Schrumpf, F., Crawford, K. D., \& Bodine, J. R. (1997). Peer mediation: Conflict resolution in schools. Champaign, Illinois: Research Press.

Senek, S. (2018). Aytül Akal'ın masallarının değerler eğitimi açısından incelenmesi. Yayımlanmamış Yüksek Lisans Tezi, Akdeniz Üniversitesi Eğitim Bilimleri Enstitüsü, Antalya.

Sever, S. (2006). Çocuk ve edebiyat. Ankara: Kök Yayıncılık.

Sezer, Ö. (2004). Masallarda toplumsal cinsiyetin işlenişi. Yayımlanmamış Yüksek Lisans Tezi, Ankara Üniversitesi Sosyal Bilimler Enstitüsü, Ankara.

Tanju Aslışen, E. H. (2017). Okul öncesi dönem çocuklarına yönelik hazırlanan resimli hikâye kitaplarındaki iletişim engelleri ve çocukların gelişimleri üzerindeki etkileri. Uluslararası Erken Çocukluk Eğitimi Çalışmaları Dergisi/International Journal of Early Childhood Education Studies, 2(10), 10-25.

Tavşancıl, E., \& Aslan, E. (2001). Sözel, yazılı ve diğer materyaller için içerik analizi ve uygulama örnekleri. İstanbul: Epsilon Yayınevi.

Tuğrul, B. (2002). 4-10 yaş grubunda çocukları olan ailelerin çocuk kitapları hakkındaki görüşlerinin ve tutumlarının incelenmesi. Çukurova Üniversitesi Eğitim Fakültesi Dergisi, 2(22), 21-30.

Tür, G., \& Turla, A. (1999). Okul öncesinde çocuk, edebiyat ve kitap. İstanbul: YA-PA Yayınları.

Turan, S. (2011). Masalların çocuk hakları bağlamında çözümlenmesi ("Her güne bir masal" adlı kitap üzerine bir inceleme). Yayımlanmamış Yüksek Lisans Tezi, Ankara Üniversitesi Eğitim Bilimleri Enstitüsü, Ankara.

Türk Dil Kurumu [TDK] (2019). Sözlük'te çatışma. http://www.tdk.gov.tr/index.php?option=com_bts\&view=bts\&kategori1=veritbn\&kelimesec $=70892$ 'den alınmıştır. Erişim Tarihi: 20.09.2019.

Türnüklü, A. (2006). Sınıf ve okul disiplinine çağdaş bir yaklaşım- onarıcı disiplin: Okullarda yaşanan kişiler arası çatışmaları yapıcı ve barış̧ıl olarak yönetmek için çağdaş bir model. Ankara: Ekinoks Yayınları.

Uğurlu, S. B. (2013). Resimli çocuk kitaplarında hayvan karakter kullanımı. Turkish Studies International Periodical for The Languages, Literature and History of Turkish or Turkic, 8(4), 1381-1393.

Yalçın, A., \& Aytaş, G. (2005). Çocuk edebiyatı (3. baskı). Ankara: Akçağ Basım Yayın Pazarlama.

Yıldırım, A., \& Şimşek H. (2008). Sosyal bilimlerde nitel araştırma yöntemler (6. baskı). Ankara: Seçkin Yayıncilık.

Yükselen, A., Yumuş, M., \& Işık, E. (2016). Çocuk kitabı seçme kriterlerine ilişkin okul öncesi eğitimcilerin görüşleri. Başkent Unıversity Journal of Education, 3(2), 161-168.

\section{Purpose and Significance}

\section{Extended Abstract}

The general purpose of this study is to make an investigation about the conflicts that stand out in the Aytül Akal's preschool fairy tales series. In line with this general purpose; answers to the following questions were sought: (1) What/who are the main characters of the prominent conflicts in the fairy tales included in the Aytül Akal's preschool fairy tales series?, (2) What are the reasons for the occurrence of the prominent conflicts in the fairy tales included in the Aytül Akal's preschool fairy 
tales series?, and (3) What are the manners of solutions for the prominent conflicts that stand out in the fairy tales included in the Aytül Akal's preschool fairy tales series?

\section{Method}

In this study the case study design, among the qualitative research methods, was used to analyze the conflicts in the fairy tales included in the Aytül Akal's preschool fairy tales series. The study set is comprised of 20 fairy tale books procured according to the sampling method available to the researcher, among the 52 fairy tale books in the fairy tales series written by Aytül Akal and published by Uçanbalık Publishing Company, under the category of preschool books. These fairy tales are (1) Who Does This World Belong To? (Bu Dünya Kimin?), (2) I Am Big (Ben Büyüküm), (3) A Creased Piece Of Paper (Buruşuk Kâğıt Parçası), (4) All Toys Are Mine (Bütün Oyuncaklar Benim), (5) Who Will Sleep In The Big Bed? (Büyük Yatakta Kim Yatacak?), (6) The Witch Nosed Factory (Cadı Burunlu Fabrika), (7) The Bored Moon (Canı Sıkılan Aydede), (8) The Chocolate Kid (Çikolata Çocuk), (9) The Steamer That Wonders The Undersea (Denizin Altını Merak Eden Vapur), (10) The Most Beautiful Tree Of The World (Dünyanın En Güzel Ağacı), (11) The Tree That Likes Wandering (Gezmeyi Seven Ağaç), (12) The Kid Wandering Around The Lights (Işıkları Dolaşan Çocuk), (13) The Star That Loses Its Light (Işığını Yitiren Yıldız), (14) The Two Aggressive Trees (iki Kavgacı Ağaç), (15) The Elephant With Measles (Kızamık Olan Fil), (16) Who Has The Colors Of The Forest (Ormanın Renkleri Kimde), (17) The Robot Who Eats Parks (Park Yiyen Robot), (18) The Ball Looking For Its Color (Rengini Arayan Top), (19) The Spoiled Elephant (Şımarık Fil) and (20) The Naughty Traffic Light (Yaramaz Trafik Lambası). The technique of document review was used to collect the data of this study, which was conducted according to qualitative research method. Content analysis was also used to analyze the data obtained in line with the purpose of the study.

\section{Results, Discussion and Recommendations}

It was found in the study that some of the main characters in the Aytül Akal's fairy tales in the study set were composed of living creatures as humans $(f=5)$, animals $(f=4)$, and plants $(f=3)$, while some of them were composed of non-living things $(f=7)$. A fairy tale in which both living and non-living things are the main characters was also found. For example, the main character is a piece of paper left on the roadside in $A$ Creased Piece of Paper, a child who wanders around the lights as he does not want to sleep in The Kid Wandering Around The Lights, a baby elephant that does not want to sleep in its own bed and sleeps in its parents' bed in Who Will Sleep In The Big Bed?, a small streamer that carries people from one coast to the other coast in The Streamer That Wonders The Undersea, a tree that gets so bored and changes its hair style one day in The Most Beautiful Tree Of The World, and a colorless ball that is late for the color choosing day in The Ball Looking For Its Color. Evaluating the reasons why the prominent conflicts in the fairy tales in the study group occur, it was detected that the conflicts occur due to different perception of values at the most $(f=7)$, then the desire to have fun $(f=5)$ and power requirement $(f=5)$, followed by being free $(f=2)$ and limitation of sources $(f=1)$. Accordingly, the fact that the conflicts occurring due to different perception of values (A Creased Piece Of Paper, All Toys Are Mine, The Chocolate Kid, The Star That Loses Its Light, Who Has The Colors Of The Forest, The Robot Who Eats Parks) are high is an expression indicating that a different imagination and a different mentality dominate in the childhood period. In the fairy tales that highlight the conflicts occurring due to power requirement (I Am Big, Who Does This World Belong To?, The Two Aggressive Trees, The Ball Looking For Its Color, and The Spoiled Elephant), giving the impression of the situations such as refusing to accept oneself small (I Am Big), thinking oneself as the owner of the world (Who Does This World Belong To?), and prioritizing one's own desires (The Two Aggressive Trees) corresponds to the preschool children reality. Situations parallel to these conditions are also found in the fairy tales that highlight the conflicts occurring based on the desire to be free (Who Will Sleep In The Big Bed?, The Tree That Likes Wandering). Meanwhile, It was also detected that the conflict resolution manners varying in the form of facing the result of the behavior $(f=11)$, agreement with other opinions $(f=4)$, being in cooperation $(f=3)$, and adaption to the condition $(f=2)$ were addressed in the process of resolution of the prominent conflicts in the fairy tales. Thus, it was determined that the conflicts in the 
fairy tales that are analyzed within the scope of the study are not solved by means of use of violence, use of force, ensuring withdrawal, but are solved by means of constructive problem-solving strategies such as seeing/facing the problem condition and coming to an agreement-cooperation to solve the problem. For example, the aggressive tree does not yield fruits (in The Two Aggressive Trees) and the traffic light that works reverse disturb the order (in The Naughty Traffic Light), but it was revealed as a result of these, giving up the improper behavior is a way that takes the characters to unity and solidarity and peace, without using any magical ways. In this scope, the fact that the conflicts in the fairy tales in the study are solved with a win-win aspect and it is expressed that the parties find happiness at the end is an expression that they are the kind of fairy tales that can support the development of children. Correspondingly, it is mandatory that preschool teachers and parents reach at a high level of awareness and sensitivity in terms of qualified children's literature works, benefiting from written, verbal, and visual sources of communications. 